\title{
34. LAPIDEACASSIS AND SCAMPANELLA, CALCAREOUS NANNOFOSSILS FROM THE PALEOCENE AT SITES 354 AND 356, DSDP LEG 39, SOUTHERN ATLANTIC
}

\author{
Katharina Perch-Nielsen and Helmut E. Franz, \\ Geological Department, Federal Institute of Technology, Zürich, Switzerland
}

\begin{abstract}
Seven new species of the genera Lapideacassis Black and Scampanella Forchheimer and Stradner are described from the Paleocene at Site 354 on the Ceará Rise and Site 356 on São Paulo Plateau: $L$. blackii, L. multispinata, L. trispina, $S$. asymmetrica, S. bispinosa, $S$. magnifica, and $S$. wisei. A new terminology is applied to describe the forms of the two genera, and illustrations of all forms of the genera known to date are given.
\end{abstract}

\section{INTRODUCTION}

During the stratigraphic work on Leg 39 samples using a light microscope, K.P.N. noted the presence of rare to very rare forms similar to the genera Lapideacassis and Scampanella in one Upper Cretaceous and several Paleocene and even Eocene samples. The genera had previously only been described with electronmicroscopy. Such forms were also found at Sites 330 and 327 in the Albian and at Site 329 in the Maestrichtian of Leg 36 on the Falkland Plateau (Wind and Wise, 1977). H.F. therefore made a special effort to find and illustrate specimens from the Paleocene of Sites 354 and 356 of Leg 39 (Figure 1). To our surprise, we discovered that the specimens, found after long searches, could be assigned to the two genera described by Black (1971) and Forchheimer and Stradner (1973). Most, however, belong to new species rather than to species previously described.

The unusual shape and construction of these nannoliths makes it difficult to describe them accurately without a specialized terminology. The terms applied here in the description of the various species on hand are shown on a theoretical nannolith (Figure 2).

\section{SYSTEMATIC PALEONTOLOGY}

The genera Lapideacassis Black and Scampanella Forchheimer and Stradner have not yet been assigned to a family. Wind and Wise (1977) considered the two genera to be synonymous, a view not supported by the present authors.

Generally, all named species consist of a body built of a proximal column, a proximal tier, one or more distal tiers and can have an apical cone, an apical-central or asymmetrical-process, and/or apical spines. In Scampanella, only the first distal tier is present which constitutes more than half of the length of the body. In Lapideacassis, the number of distal tiers is greater than one. The species in both genera are defined by the presence or absence, number, shape, and orientation, of the apical cone, apical spines, and apical process, and in Lapideacassis also by the number of distal tiers. Table I shows the presence or absence of these characteristics in all species in the two genera thus far described. All species are shown in Figure 3.

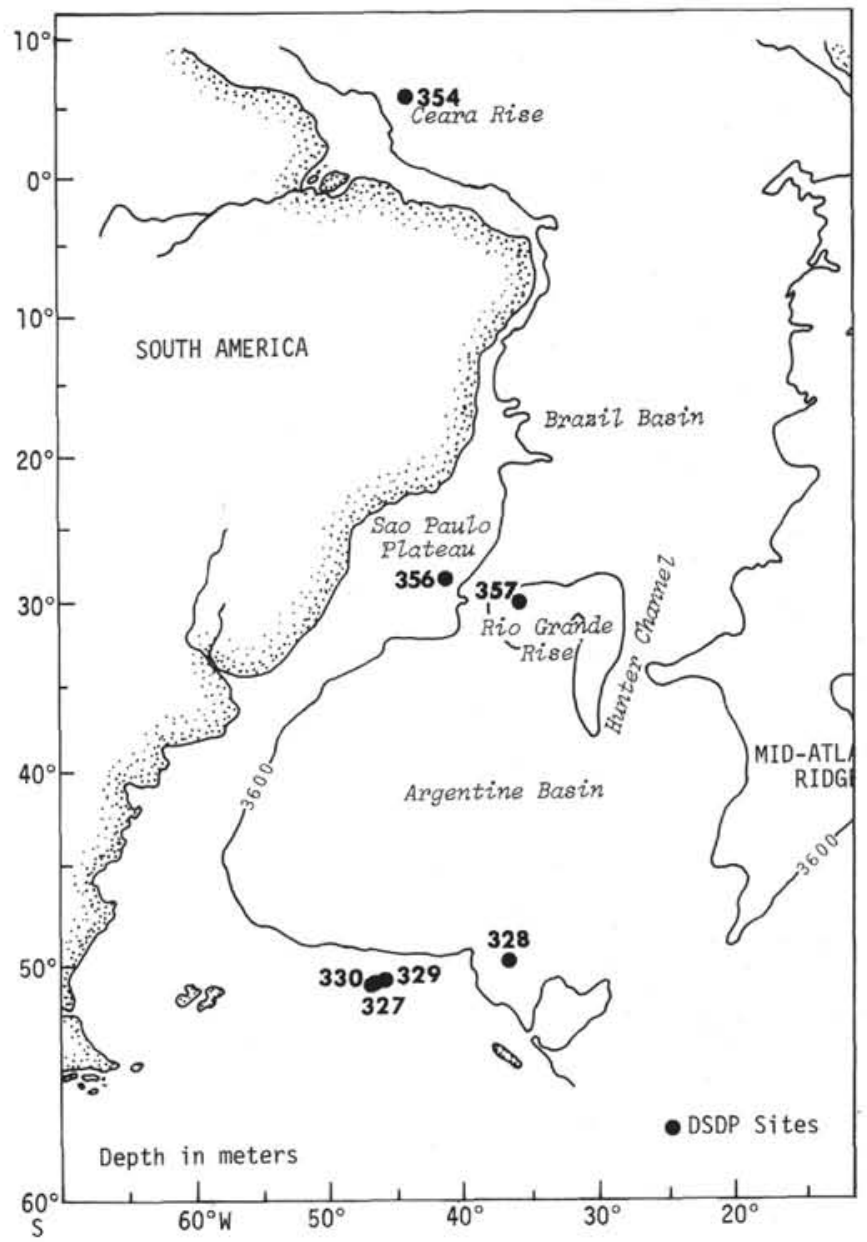

Figure 1. Location of the Leg 36 and 39 sites mentioned in the text.

Lapideacassis Black, 1971

Type Species: L. mariae Black, 1971.

Black described Lapideacassis as "bell-shaped" microfossils with walls composed of vertically elongated plates arranged in several 


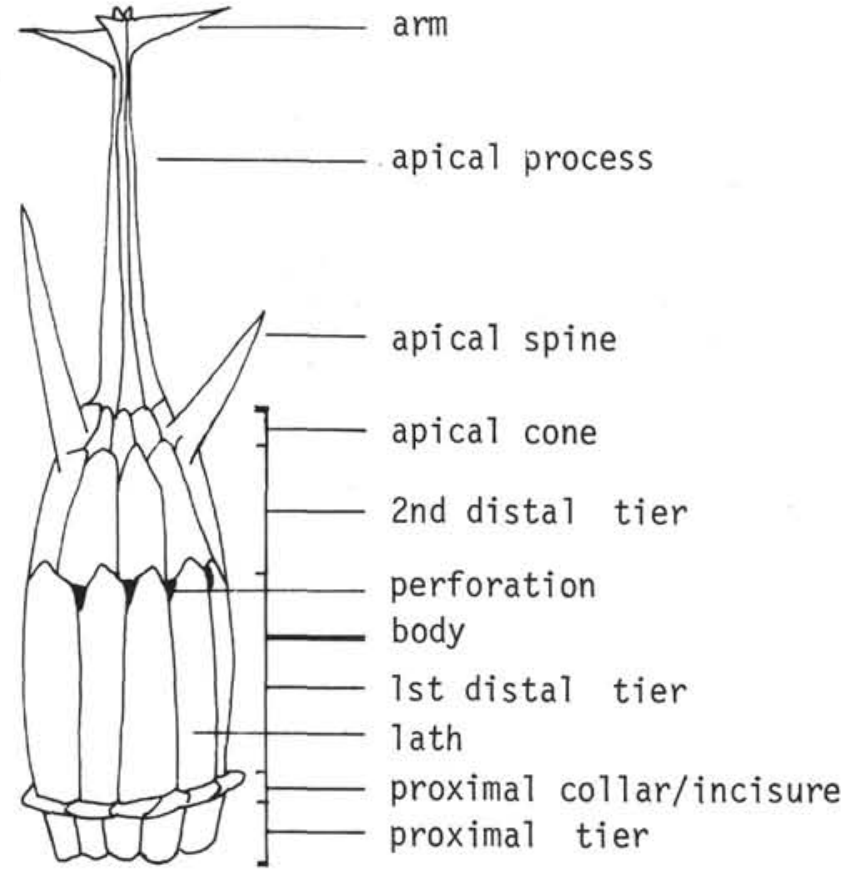

Figure 2. Hypothetical form to show terms applied to describe specimens of Scampanella and Lapideacassis.

tiers." Thus Lapideacassis differs from Scampanella by the presence of more than one tier and consequently we do not include Scampanella in Lapideacassis, as suggested by Wind and Wise (1977).

\section{Lapideacassis blackii Perch-Nielsen, n. sp.} (Plate 2, Figures 7, 8; Text figure 3:5)

Holotype: Plate 2, Figure 7.

Type level: Early Paleocene (NP3, Chiasmolithus danicus Zone). (possibly reworked from the Cretaceous).
Type locality: DSDP Site 356, Sào Paulo Plateau.

Diagnosis: Nannolith with proximal tier, two distal tiers, and an apical cone extending into an apical, central process.

Description: The proximal tier is short and no proximal collar is present. The first distal tier is higher than the second one and builds a parallel-sided body. The second distal tier is conical. The apical cone is short and supports the central apical process which seems to consist of four laths, all continuations from elements of the apical cone. The apical process is incomplete in both specimens shown on Plate 2. In the holotype, a row of elongated perforations occurs between the apical cone and the second distal tier and signs of perforations are visible between the latter and the first distal tier.

Remarks: L. blackii differs from other species of Lapideacassis in having a central apical process. The type species of Lapideacassis, $L$. mariae has a well developed proximal collar but whether the holotype had an apical process or spine, or any apical structures above the low apical cone cannot be determined.

Occurrence: L. blackii was found in Sample 356-28-3, $70 \mathrm{~cm}$, of Paleocene age.

\section{Lapideacassis glans Black, 1971} (Text figure 3:1)

1971 Lapideacassis glans Black, p. 326, 327, pl. 1c, not 1d. 1977 Lapideacassis glans Black in Wind and Wise, p. 301, pl. 47, fig. 5; not pl. 46, fig. 5, 6, and pl. 47, fig. 6 .

Description: Hemispherical nannolith with a prominent proximal tier and a well-developed proximal collar. The first and second distal tiers are of about equal height; the reduced apical cone is rounded. Remains of apical spines are extremely indistinct on the holotype.

Remarks: Black (1971) described L. glans as "a species of Lapideacassis with roughly sculptured calcite plates having no visible perforations", and thus included in the species a higher form with three distal tiers and an apical cone (Plate Id). This specimen is here considered to be a different form, Lapideacassis sp. I. Wind and Wise (1977) have figured three specimens assigned to L. glans. Only the specimen in their pl. 47, fig. 5 , might, according to the present authors, belong to L. glans. The others belong to Lapideacassis sp. 2 (pl. 46, fig. 5, 6) and Lapideacassis sp. 1 (pl. 47, fig. 6).

Occurrence: The holotype of L. glans was described from the Upper Gault of Kent, England. The specimen figured by Wind and Wise (1977) and here left in L. glans was found in the Albian of Site 330 on the Falkland Plateau.

TABLE 1

Stratigraphic Occurrence of Scampanella and Lapideacassis (from Black, 1971; Forchheimer and Stradner, 1973; Wind and Wise, 1977; and this report) and the Presence of Structural Elements in the Different Species and Specimens of the Two Genera

\begin{tabular}{|c|c|c|c|c|c|c|c|c|c|c|c|c|c|c|c|c|c|}
\hline \multirow{4}{*}{$\begin{array}{l}\text { Middle Eocene } \\
\text { Late Paleocene } \\
\text { Early Paleocene } \\
\text { Cretaceous }\end{array}$} & \multicolumn{4}{|r|}{$\mathrm{X}$} & & \multirow{4}{*}{\multicolumn{3}{|c|}{$X$}} & \multirow{4}{*}{$\begin{array}{r}\mathrm{X} \\
\mathrm{X} \\
\mathrm{X}\end{array}$} & \multirow{2}{*}{\multicolumn{3}{|c|}{ ? }} & & \multirow{4}{*}{$\mathrm{X}$} & \multirow[t]{4}{*}{$\mathrm{X}$} \\
\hline & & & & & $X$ & & \multirow{3}{*}{$\mathrm{X}$} & & & & & & & & & & \\
\hline & $\mathrm{X}$ & & & & $X$ & & & & & & & & $\mathrm{X}$ & & & & \\
\hline & & $\mathrm{X}$ & $\mathrm{X}$ & & & $\mathrm{X}$ & & & & & & $\mathrm{X}$ & $\mathrm{X}$ & & & & \\
\hline $\begin{array}{l}\text { Struc } \\
\text { elem }\end{array}$ & 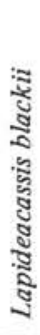 & $\underset{\substack{5 \\
-\infty}}{i}$ & 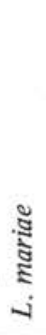 & 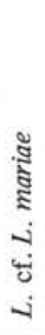 & 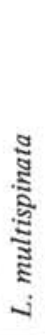 & 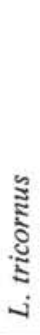 & 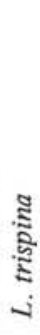 & के & $\begin{array}{l}\text { iे } \\
\text { के }\end{array}$ & 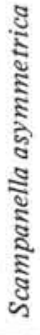 & 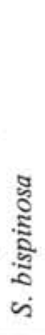 & 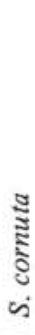 & 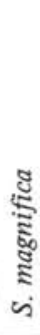 & $\begin{array}{l}\tilde{\mathscr{Z}} \\
\vdots \\
\dot{3}\end{array}$ & $\begin{array}{l}\overrightarrow{1} \\
\text { के } \\
\text { के }\end{array}$ & $\begin{array}{l}\text { के } \\
\text { के }\end{array}$ & $\begin{array}{l}m \\
\dot{m} \\
\dot{m}\end{array}$ \\
\hline & & $\mathrm{X}$ & $\mathrm{X}$ & $\mathrm{X}$ & $\mathrm{x}$ & $\mathrm{X}$ & $\mathrm{X}$ & $\mathrm{X}$ & $\mathrm{X}$ & $?$ & $\mathrm{X}$ & $x$ & $\mathrm{X}$ & $\mathrm{X}$ & $?$ & & \\
\hline Pro & ? & $\mathrm{X}$ & $\mathrm{X}$ & $\mathrm{X}$ & $\mathrm{X}$ & $\mathrm{X}$ & $\mathrm{X}$ & $\mathrm{X}$ & $X$ & ? & $\mathrm{X}$ & $\mathrm{X}$ & X & X & $?$ & 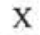 & $\lambda$ \\
\hline D & & $\mathrm{X}$ & $\mathrm{X}$ & $\mathrm{X}$ & $\mathrm{X}$ & $X$ & $\mathrm{X}$ & $\mathrm{X}$ & $\mathrm{X}$ & X & $\mathrm{X}$ & $\mathrm{X}$ & $\mathrm{X}$ & $\mathrm{X}$ & $?$ & $X$ & $\mathrm{X}$ \\
\hline D & & $\mathrm{X}$ & $\mathrm{X}$ & $\mathrm{X}$ & $\mathrm{X}$ & $\mathrm{X}$ & $\mathrm{X}$ & $\mathrm{X}$ & $\mathrm{X}$ & - & - & - & - & - & $?$ & - & - \\
\hline Dis & & - & - & $?$ & - & - & - & $\mathrm{X}$ & $\mathrm{X}$ & - & - & - & - & - & $?$ & - & - \\
\hline Apic & $\mathrm{X}$ & $\mathrm{X}$ & $\mathrm{X}$ & & $\mathrm{X}$ & $\mathrm{X}$ & $\mathrm{X}$ & $\mathrm{X}$ & $\mathrm{X}$ & $\mathrm{X}$ & - & $\mathrm{X}$ & $\mathrm{X}$ & $\mathrm{X}$ & $\mathrm{X}$ & $\mathrm{X}$ & $?$ \\
\hline Apical proce & $X$ & $?$ & $?$ & & - & - & - & $?$ & - & $\mathrm{X}$ & - & - & $\mathrm{X}$ & - & $\mathrm{X}$ & $?$ & \\
\hline Apical spines & & $?$ & $?$ & & $>3$ & 3 & 3 & ? & - & - & 2 & 2 & - & 3 & - & $?$ & ?1 \\
\hline Cylindrical & $\lambda$ & & $\mathrm{X}$ & & $\mathrm{X}$ & $\mathrm{X}$ & $\mathrm{X}$ & $\mathrm{X}$ & & $\mathrm{X}$ & $\mathrm{X}$ & $\mathrm{X}$ & $\mathrm{X}$ & $\mathrm{X}$ & & $\mathrm{X}$ & \\
\hline Hemisp & & $\mathrm{X}$ & & & & & & & $X$ & & & & & & & & \pm \\
\hline
\end{tabular}




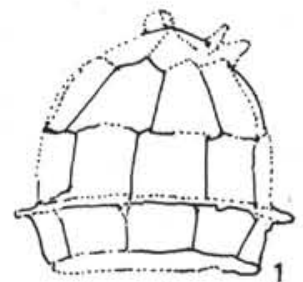

L. glans

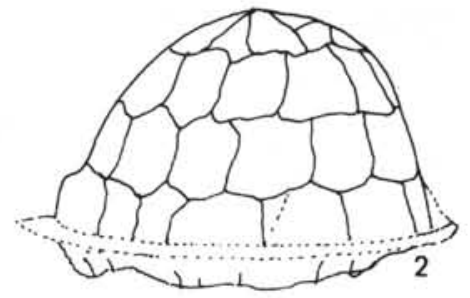

Lapideacassis sp. 2 Lapideacassis sp. 1

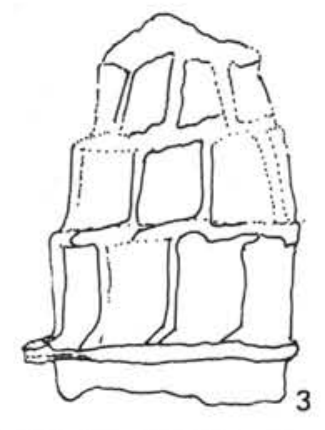

1

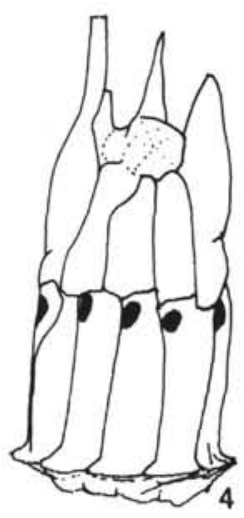

L. tricornus

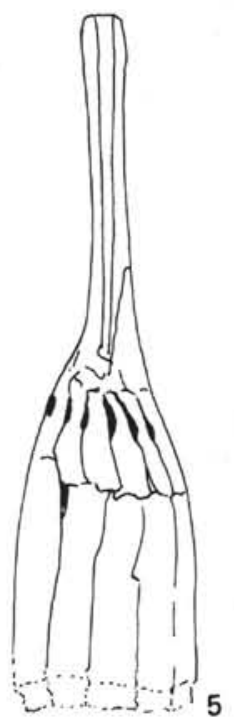

L. blackii

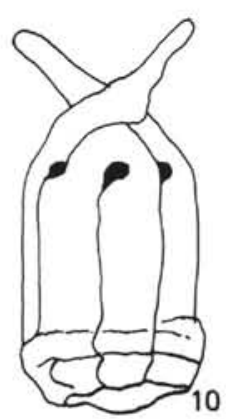

S. cornuta

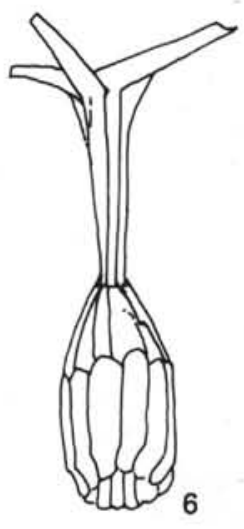

S. magnifica

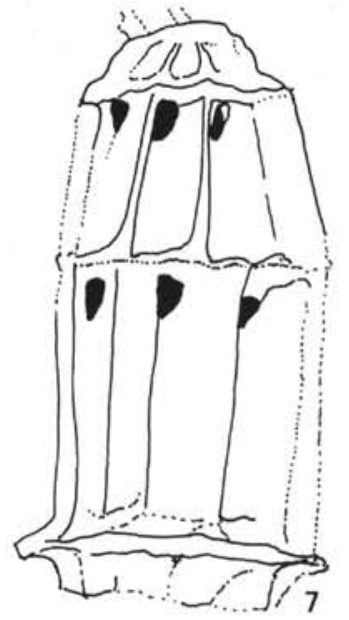

L. mariae

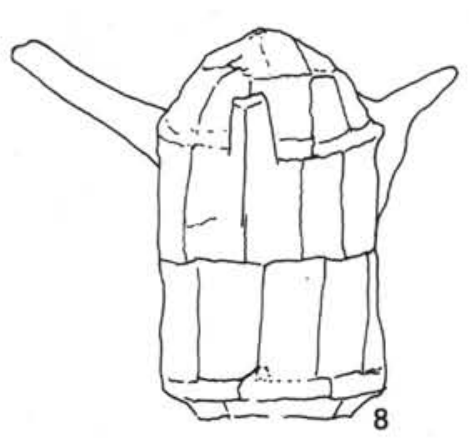

L. trispina

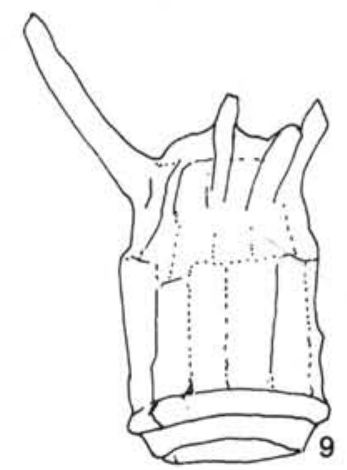

L. multispinata

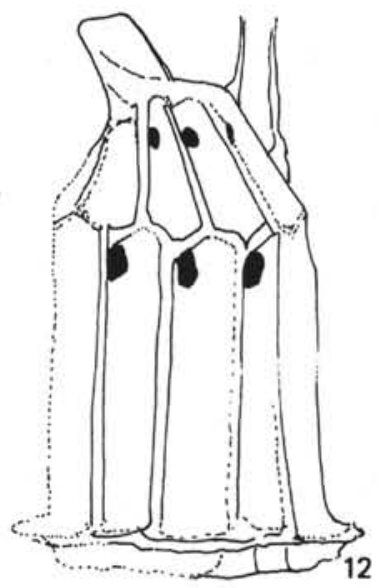

Scampanella sp. 2

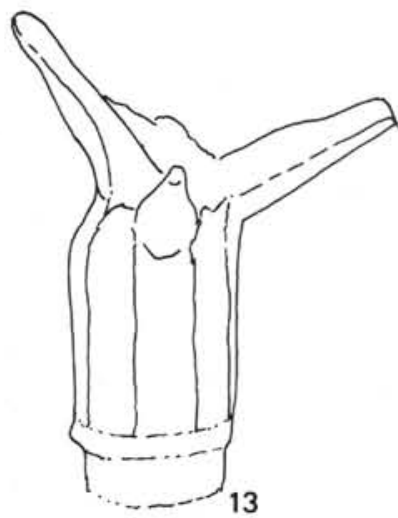

S. wisei

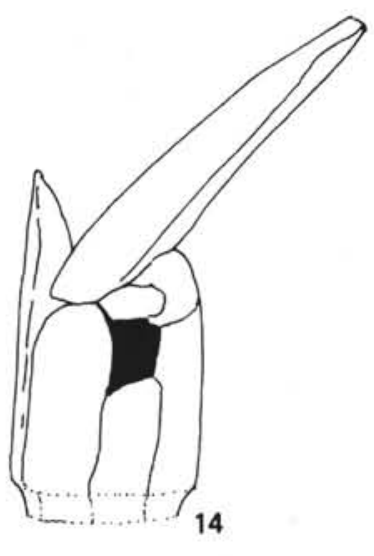

S. bispinosa

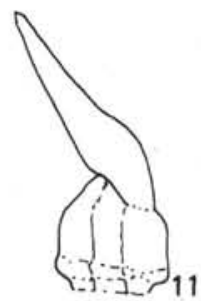

Scampanella sp. 3

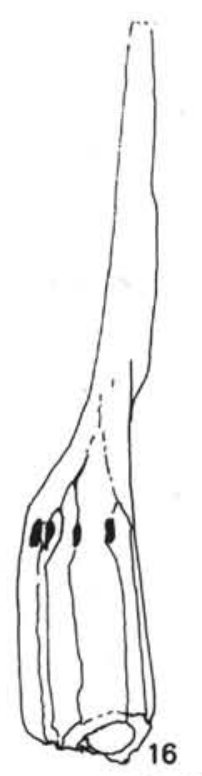

S. asymmetrica

Figure 3. Sketches of species and specimens of Scampanella and Lapideacassis, described to date. 


\section{Lapideacassis mariae Black, 1971}

(Text figure $3: 7$ )

1971 Lapideacassis mariae Black, p. 326, pl. 1b, not 1a.

NOT 1977 Lapideacassis mariae Black in Wind and Wise, p. 301, pl. 46 , fig. 1-3; pl. 47 , fig. 1, 2; pl. 49, fig. $1,2$.

Description: Nannolith with a short proximal tier and a welldeveloped proximal collar. The first distal tier is somewhat higher than the slightly tapering second one and the apical cone is reduced and rounded. It is not clear, whether the holotype has apical spines, an apical process, or additional apical elements at all. Perforations occur at the top of both distal tiers.

Remarks: Black (1971) described L. mariae as "a species of Lapideacassis with smooth-surfaced calcite plates and a small perforation near the aboral end of each plate." The species was emended by Wind and Wise (1977) on the basis of specimens here considered to belong to Scampanella magnifica and not to L. mariae as represented by the holotype. The two specimens figured by Black are not the same species according to the present authors, thus only the holotype is left in L. mariae and the other form is assigned to Scampanella sp. While L. mariae adequately characterizes the genus which it defines, because the presence or absence of apical spines or an apical process cannot be defintely established, it does not adequately define the species.

Occurrence: The holotype of $L$. mariae was described from the Gault of Suffolk, England.

\section{Lapideacassis ef. L. mariae Black, 1971}

(Plate 6, Figures 31-35)

Remarks: Only a light microscope picture is available of $L$. cf. $L$. mariae from the middle Eocene at Site 356. The specimen is higher than most other Lapideacassis and bears an unknown number of apical spines. L. mariae probably has fewer spines.

Lapideacassis multispinata Perch-Nielsen, n. sp.

(Plate 4, Figures 4-6, 7, 9; Plate 6, Figures, 24 25, 28-30; Text figure 3:9)

Holotype: Plate 4, Figures 4-6, 9.

Type level: Early Paleocene (NP4 Ellipsolithus macellus Zone). (Possibly reworked from the Cretaceous).

Type locality: DSDP Site 356, São Paulo Plateau.

Diagnosis: Nannolith with a proximal tier, a proximal collar, two distal tiers, an apical cone and more than three apical spines.

Description: The proximal tier is short and consists of overlapping elements. The proximal collar is well developed. The first distal tier is slightly higher than the second one and both consist of 8 to 10 plates. The apical cone is low and rounded. The apical spines, at least six in the holotype, are oriented radially to slightly tangentially at an angle of about $45^{\circ}$.

Remarks: No other species of Lapideacassis or Scampanella has more than three apical spines.

Occurrence: L. multispinata was found in Samples 356-28-3, 70 $\mathrm{cm}, 356-25-5,70 \mathrm{~cm}$, and $356-23-2,70 \mathrm{~cm}$, of early and late Paleocene age.

\section{Lapideacassis tricornus Wind and Wise, 1977}

\section{(Text figure: $3: 4$ )}

1977 Lapideacassis tricornus Wind and Wise, p. 301, pl. 46, fig. 4; pl. 48 , fig. $1-8$.

Description: Nannolith with a short proximal tier, a welldeveloped proximal collar, two distal tiers of about equal length, a reduced, rounded apical cone and three almost vertically oriented apical spines. Perforations occur between the two distal tiers.

Remarks: L. tricormus is the only species of Lapideacassis with three almost vertical apical spines. Wind and Wise (1977) have also included one of the two specimens of L. mariae shown by Black (1971) into L. tricornus. We did not do this here, because in the specimen described by Black (1971, pl. 1a), the first distal tier is much higher than the second one which is, in fact, an apical cone rather than a distal tier. Also the number and orientation of the apical spines is not clear from Black's illustration.

Occurrence: L. tricornus was described from the Maestrichtian at DSDP Site 327 on the Falkland Plateau. It was not observed in the Leg 39 material.
Lapideacassis trispina Perch-Nie!sen, n. sp.

(Plate 4, Figures 1-3, 8; Plate 5, Figures 1, 3, 4, 6, 7, 9; Plate 6, Figures 21-23, 26, 27; Tex, figure 3:8)

Holotype: Plate 4, Figures 1-3.

Type level: Early Paleocene (NP3, Chiasmolithus danicus Zone) (possibly reworked from the Cretaceous).

Type locality: DSDP Site 356, São Paulo Plateau.

Diagnosis: Nannolith with a proximal tier and collar, two distal tiers, an apical cone and three apical spines. The spines are nearly horizontal and at an angle of $120^{\circ}$ to each other in apical projection.

Description: The proximal tier is short and consists of overlapping elements. The proximal collar is well developed in some specimens. The distal tiers are of nearly equal height and consist of about 10 to 12 elongated elements. The apical cone is rounded. The apical spines develop from the upper part of elements of the second distal tier and are oriented slightly upwards, about $20^{\circ}$ above horizontal.

Remarks: $L$. trispina differs from $L$. tricornus by the orientation of the apical spines which is very steep, almost vertical, in $L$. tricornus. S. wisei, which also has three apical spines has a higher proximal tier and asymmetrically arranged spines. It also has only one distal tier.

Occurrence: L. trispina was found in Samples $356-28-3,70 \mathrm{~cm}$, and 356-29-1, $90 \mathrm{~cm}$, of early Paleocene age.

\section{Lapideacassis sp. 1 \\ (Text figure 3:3)}

1971 Lapideacassis glans Black, p. 326, 327; pl. Id, not Ic.

1977 Lapideacassis glans Black in Wind and Wise, p. 301; pl. 47, fig. 6 , not 5 and not pl. 46 , fig. 5,6 .

Description: Cylindrical nannolith with a proximal tier, a well developed proximal collar and three distal tiers. The first distal tier is higher than the second one which likewise is higher than the third tier. The first distal tier consists of about 10 , the second of 6 to 10 , and the third of 6 to 8 elements. The apical cone is reduced and rounded. No remains of apical spines or of an apical process are visible on the two specimens illustrated thus far.

Remarks: Lapideacassis sp. I and Lapideacassis sp. 2 are the only forms of the genus that have three distal tiers: $\mathrm{sp.} 1$ is cylindrical and sp. 2 is hemispherical. Text figure $3: 3$ was taken from the TEM by Black (197I). The specimen figured by Wind and Wise (1977) is less well preserved and neither proximal collar nor tier were preserved.

Occurrence: Black's specimen was found in the Upper Gault of Kent, England. The specimen illustrated by Wind and Wise (1977) is from the Albian at DSDP Site 330.

\section{Lapideacassis sp. 2}

(Text figure $3: 2$ )

1977 Lapideacassis glans Black in Wind and Wise, p. 301, pl. 46, fig. 5,6 , not pl. 47 , fig. 5,6 .

Description: Hemispherical nannolith with a short proximal tier, a well-developed proximal collar and three distal tiers of about equal height but with decreasing number of elements. The first distal tier consists of about 16 elements, the second of about 12, and the third of about 10 , nearly quadrangular plates. The apical cone is rounded. No remains of an apical process or of apical spines can be seen on the specimen figured by Wind and Wise (1977) and shown on Text figure $3: 2$.

Remarks: Lapideacassis sp. 2 and Lapideacassis sp. 1 are the only forms of the genus with three distal tiers, and Lapideacassis sp. 2 is the only hemispherical form besides $L$. glans, to which the specimen was assigned by Wind and Wise (1977). We consider L. glans to be restricted to forms with only two distal tiers.

Occurrence: Lapideacassis sp. 2 was found in the Maestrichtian of DSDP Site 327 on the Falkland Plateau.

\section{Scampanella Forchheimer and Stradner, 1973 emend.}

Type Species: $S$. cornuta.

The original definition of Scampanella included coccoliths with one distal tier and two apical spines. It is here emended to include also forms with an apical process or one or more apical spines. An apical cone may or may not be present. Scampanella was included by Wind and Wise (1977) in Lapideacassis but we consider Lapideacassis here to be a separate genus with two or more distal tiers. 
Scampanella asymmetrica Perch-Nielsen, n. sp.

(Plate 2, Figures 3-6, 9, 10; Plate 6, Figures 7-9; Text figure $3: 16$ )

Holotype: Plate 2, Figures 9, 10.

Type level: Early Paleocene (NP3, Chiasmolithus danicus Zone) (possibly reworked from the Cretaceous).

Type locality: DSDP Site 356, Sào Paulo Plateau.

Diagnosis: Nannolith consisting of a proximal tier, a proximal collar, a high distal tier, and an asymmetrical apical cone extending to a high apical process.

Description: The proximal tier, (missing on the holotype) is short and the proximal collar is reduced. The distal tier is very high and separated from the apical cone by a row of perforations. A long apical process sits asymmetrically on the apical cone.

Remarks: $S$. asymmetrica is the only Scampanella with an asymmetrical apical process.

Occurrence: $S$. asymmetrica was found in Sample 356-28-3, 70 $\mathrm{cm}$, of early Paleocene age.

Scampanella bispinosa Perch-Nielsen, n. sp.

(Plate 3, Figures 1-7; Plate 6, Figures 12-14, 15-17; Text figure $3: 14$ )

Holotype: Plate 3, Figures 4-7.

Type level: Early Paleocene (NP4, Ellipsolithus macellus Zone) (possibly reworked from the Cretaceous).

Type locality: DSDP Site 356, São Paulo Plateau.

Diagnosis: Nannolith with a proximal tier, a proximal collar, a distal tier, and two apical spines, one vertical and one pointing at an angle of about $45^{\circ}$.

Description: The proximal tier is relatively high in the holotype, but missing in the other specimen illustrated on Plate 3. The distal tie consists of 6 to 8 plates and perforations can be seen at its top in the holotype. The vertically oriented apical spine extends directly from an element of the distal tier.

Remarks: $S$. bispinosa differs from $S$. cornuta, the type species of Scampanella, by the orientation of the apical spines.

Occurrence: $S$. bispinosa was found in Sample $356-25-5,70 \mathrm{~cm}$, of early Paleocene age; in Sample 354-16-6, $70 \mathrm{~cm}$, of late Paleocene age; and in Sample $356-7-3,70 \mathrm{~cm}$, of middle Eocene age.

\section{Scampanella cornuta Forchheimer and Stradner, 1973}

(Text figure 3:10)

1973 Scampanella cornuta Forchheimer and Stradner, p. 285-289, fig. $1-9$.

1977 Lapideacassis cormuta (Forchheimer and Stradner) Wind and Wise, p. 300 , pl. 48 , fig. 11,12 ; pl. 49 , fig. 3-8.

Description: Nannolith with a short proximal tier, a high distal tier, a row of perforations between the distal tier and the apical cone, and two apical spines crossing at an angle of about $45^{\circ}$.

Remarks: $S$. cormuta is the only species of Scampanella or Lapideacassis with apical spines which cross each other.

Occurrence: $S$. cormuta was found in the Hauterivian (?) of southern Sweden (described with the SEM) and in the Coniacian of Austria (described with TEM). The specimens assigned to this species by Wind and Wise from the Albian, Cenomanian, and reworked Eocene of the Falkland Plateau are illustrated by light microscope. $S$. cornuta was not found (or not recognized ?) in the Leg 39 material.

Scampanella magnifica Perch-Nielsen, n. sp.

(Plate 1, Figures 1-5; Plate 6, Figures 4-6; Text figure 3:6)

1977 Lapideacassis mariae Black in Wind and Wise, pl. 49, fig. 1, 2; pl. 47, fig. 1, 2.

Holotype: Plate 1, Figures 1-4.

Type level: Early Paleocene (NP3, Chiasmolithus danicus Zone), (possibly reworked from the Cretaceous).

Type locality: DSDP Site 356, Sào Paulo Plateau.

Diagnosis: Nannolith with a short proximal tier, one distal tier and an apical cone bearing an apical process topped by a cross with tapering arms.

Description: The proximal tier is short and consists of about 12 elements extending into the distal tier. The relatively high apical cone consists of about 12 elements of which four extend upwards to form the apical process and the horizontally oriented cross on top of it. The arms of the cross taper.
Remarks: $S$. magnifica differs from $S$. asymmetrica by the nearly equal height of the distal tier and the apical cone in $S$. magnifica, as compared to a distal tier considerably higher than the apical cone in $S$. asymmetrica. Also, in $S$. asymmetrica the apical process does not extend from the middle of the nannolith. Perforations were not observed at the upper end of the distal tier in $S$. magnifica but occur in $S$. asymmetrica. The apical process of $S$. campanella sp. I consists of the extensions of all elements of the apical cone, while the apical process of $S$. magnifica is built only by four of the twelve elements forming the apical cone.

Occurrence: $S$. magnifica was found in Sample $356-28-3,70 \mathrm{~cm}$ of Paleocene age. It was also found in the Maestrichtian of Tunisia (personal observation) and in DSDP Sample 327A-12, CC, of Maestrichtian age (Wind and Wise, 1977).

Scampanella wisei Perch-Nielsen, n. sp.

(Plate 5, Figures 2, 5, 8; Plate 6, Figures 1-3, 10, 11, 18-20; Text figure $3: 13$ )

Holotype: Plate 5, Figures 2, 5, 8.

Type level: Early Paleocene (NP3 Chiasmolithus danicus Zone) (possibly reworked from the Cretaceous).

Type locality: DSDP Site 356, São Paulo Plateau.

Diagnosis: Nannolith with a proximal tier, a distal tier, and an apical cone from which three asymmetrically arranged apical spines extend.

Description: The proximal tier is narrow and high. The distal tier is high and topped by an apical cone. The three apical spines radiate at different angles from the apical cone or its base.

Remarks: $S$. wisei is the only Scampanella with three apical spines and the only known form in Scampanella or Lapideacassis with three asymmetrically arranged spines.

Occurrence: $S$. wisei was found in Sample $356-28-3,70 \mathrm{~cm}$, of early Paleocene age and in Sample 356-23-2, $70 \mathrm{~cm}$, of late Paleocene age.

\section{Scampanella? sp. 1}

(Plate 2, Figures 1, 2; Text figure 3:15)

Description: Scampanella? sp. 1 seems to consist only of an apical cone built of about 12 elements, each of which extends upwards to form a long apical process. We are unsure whether this form is complete or represents only the apical part of a Scampanella or Lapideacassis.

Remarks: Scampanella? sp. 1 differs from $S$. magnifica, $S$. asymmetrica, and $L$. blackii by the construction of the apical process and from the $S$. asymmetrica also by the asymmetrical position of the apical process in the latter.

Occurrence: Only a single specimen was found in Sample 356-28$3,70 \mathrm{~cm}$, of Paleocene age. The specimen was possibly reworked from the Cretaceous, inasmuch as other Cretaceous calcareous nannofossils occur in this sample.

Scampanella sp. 2

(Text figure 3:12)

1971 Lapideacassis mariae Black, p. 326, pl. 1a, not $1 \mathrm{~b}$.

Description: Cylindrical nannolith with a short proximal tier, a proximal collar and a high distal tier. The apical cone is relatively high and remains of two apical spines seem to be present on the specimen illustrated by Black (1971) and in Text figure 3:12. A row of perforations occurs between the distal tier and the apical cone.

Remarks: The only other Scampanella with an equally well developed apical cone is $S$. asymmetrica, which is distinguished by an asymmetrical apical process. We have removed Scampanella sp. 2 from $L$. mariae because of its different body construction.

Occurrence: The specimen figured was found in the Upper Gault of Kent, England.

\section{Scampanella sp. 3}

(Text figure 3:11)

1977 Scampanella sp. Perch-Nielsen, this volume, pl. 50, fig. 39.

Remarks: Only a light microscope picture is available of Scampanella sp. 3. The specimen was found in the middle Eocene at Site 356. It has a body with a proximal tier, a proximal collar, and a short distal tier. The body is about as high as it is wide. A prominent apical spine is oriented at about $45^{\circ}$. 


\section{CONCLUSIONS}

\section{Systematics}

We do not suggest to which existing family Scampanella and Lapideacassis could belong.

\section{Stratigraphy}

Table 1 shows the stratigraphic distribution of species of Lapideacassis and Scampanella illustrated in Black (1971), Forchheimer and Stradner (1973), Wind and Wise (1977), and in this report. Very rare specimens of Scampanella sp. were also found in the Maestrichtian at Site 357.

The oldest known form is probably not $S$. cornuta from the Hauterivian of Southern Sweden, because the "foraminiferal Hauterivian age" of the sample from 986.35 meters, where the holotype of $S$. cornuta was found, is questionable (Forchheimer, 1972). While the presence in this sample of Gartnerago obliquum Eiffellithus turriseiffeli and Kamptnerius indicate an age not older than Turonian, the presence of Marthasterites suggests a Coniacian/Santonia age. This would be more consistent with the Coniacian age of the paratype designated by Forchheimer and Stradner (1973) from Klafterbruun, Austria.

The specimens described by Black (1971) and Wind and Wise (1977) from the Albian thus must be regarded as the oldest Lapideacassis and Scampanella thus far found. None has yet been reported from the Turonian and Campanian and their presence in the Paleocene and Eocene is established in this report. Because the Tertiary specimens were found in Danian samples containing reworked Cretaceous coccoliths, we first assumed that the presence of Lapideacassis and Scampanella in Tertiary sediments was the result of reworking. The presence of specimens in upper Paleocene samples, where reworked Cretaceous forms are very rare, indicated that they more probably were in place. Moreover, their presence in middle Eocene samples that contain no Cretaceous coccoliths at all, supports the conclusion that Lapideacassis and Scampanella did live during the Paleocene and Eocene and that the Danian specimens are in place. Lapideacassis and Scampanella then are two of the rare genera that survived the widespread Late Cretaceous disappearance of calcareous planktonic micro- and nannofossils. Others are Markalius, Biscutum, Braarudosphaera, and the calcareous dinoflagellate Thoracosphaera.

\section{Paleobiogeography}

Scampanella and Lapideacassis lived in high northern and high southern latitudes of the Atlantic realm during the Albian to at least Coniacian/Santonian time. In the Maestrichtian they lived in high and mid-southern and mid-northern latitudes. The Paleocene specimens were found in sediments of mid-southern and lownorthern latitudes and in mid-southern latitudes in the middle Eocene. We hope that this report will draw the attention of other specialists to these rare calcareous nannofossils. Only then will we learn whether they were restricted to the Atlantic realm or also lived in the Indian and Pacific oceans and whether they were restricted to high latitudes in the late Early Cretaceous and subsequently moved to lower latitudes.

\section{ACKNOWLEDGMENTS}

We thank U. Gerber, ETH, Zürich for the photographic work. All SEM work was done in the SEM lab of the Federal Institute of Technology (ETH), Hönggerberg, where the SEM negatives are also stored. We thank F. Wind and W. Wise Jr. for providing the relevant parts of their Leg 36 manuscript and for comments on an early version of our manuscript.

\section{REFERENCES}

Black, M., 1971. Problematical microfossils from the Gault Clay: Geol. Mag., v. 108, p. 325-327.

Forchheimer, S., 1972. Scanning electron microscope studies of Cretaceous coccoliths from the Köpingsberg Borehole No. 1, southeast Sweden: Sveriges Geoligiske Undersökelse, Ser. C, 668, Arsbok, v. 65, p. 1-141.

Forchheimer, S. and Stradner, H., 1973. Scampanella, eine neue Gattung kretazischer Nannofossilien: Verh. Geol. B.A. Wien, p. 285-289.

Wind, F. and Wise, W., 1977. Mesozoic and Cenozoic calcareous nannofossils recovered by DSDP Leg 36 drilling on the Falkland Plateau, southwest Atlantic sector of the Southern Ocean. In Barker, P., Dalziel, I.W.D., et al., Initial Reports of the Deep Sea Drilling Project, Volume 36: Washington (U.S. Government Printing Office), p. 269-491. 


\section{PLATE 1}

Figures 1-5 Scampanella magnifica Perch-Nielsen, n. sp.

1. Distal view of holotype. $\times 5400$.

2. General view of holotype. $\times 3250$.

3 , 4. Proximal views of holotype. $\times 7200 ; \times 9000$.

5. Specimen with broken distal process; Sample $356-28-3,70 \mathrm{~cm}$, early Paleocene. $\times 6300$.

(see page 856 )

\section{PLATE 2}

Figures 1,2 Scampanella? sp. 1

1. General view. $\times 4000$.

2. Proximal view; Sample $356-28-3,70 \mathrm{~cm}$, early Paleocene. $\times 8000$.

Figures 3-6, 9, Scampanella asymmetrica Perch-Nielsen, n. sp.

10 $\times 4800, \times 5600, \times 12,800, \times 6400, \times 8000, \times 3200)$

9, 10. Holotype. Sample $356-28-3,70 \mathrm{~cm}$, early Paleocene.

\section{Figures 7,8 Lapideacassis blackii $\mathrm{n}$. sp.}

7. Holotype. Sample 356-28-3, $70 \mathrm{~cm}$, early Paleocene. $\times 4000$.

(see page 857 )

\section{PLATE 3}

Figures 1-7 Scampanella bispinosa Perch-Nielsen, n. sp.

1-3. Sample 354-16-6, 70, late Paleocene. $\times 6300$, $\times 6300, \times 7200$.

4-7. Holotype. Sample $356-25-5,70 \mathrm{~cm}$, early Paleocene. $\times 5850, \times 5850, \times 5850, \times 6300$.

(see page 858 ) 
PLATE 1
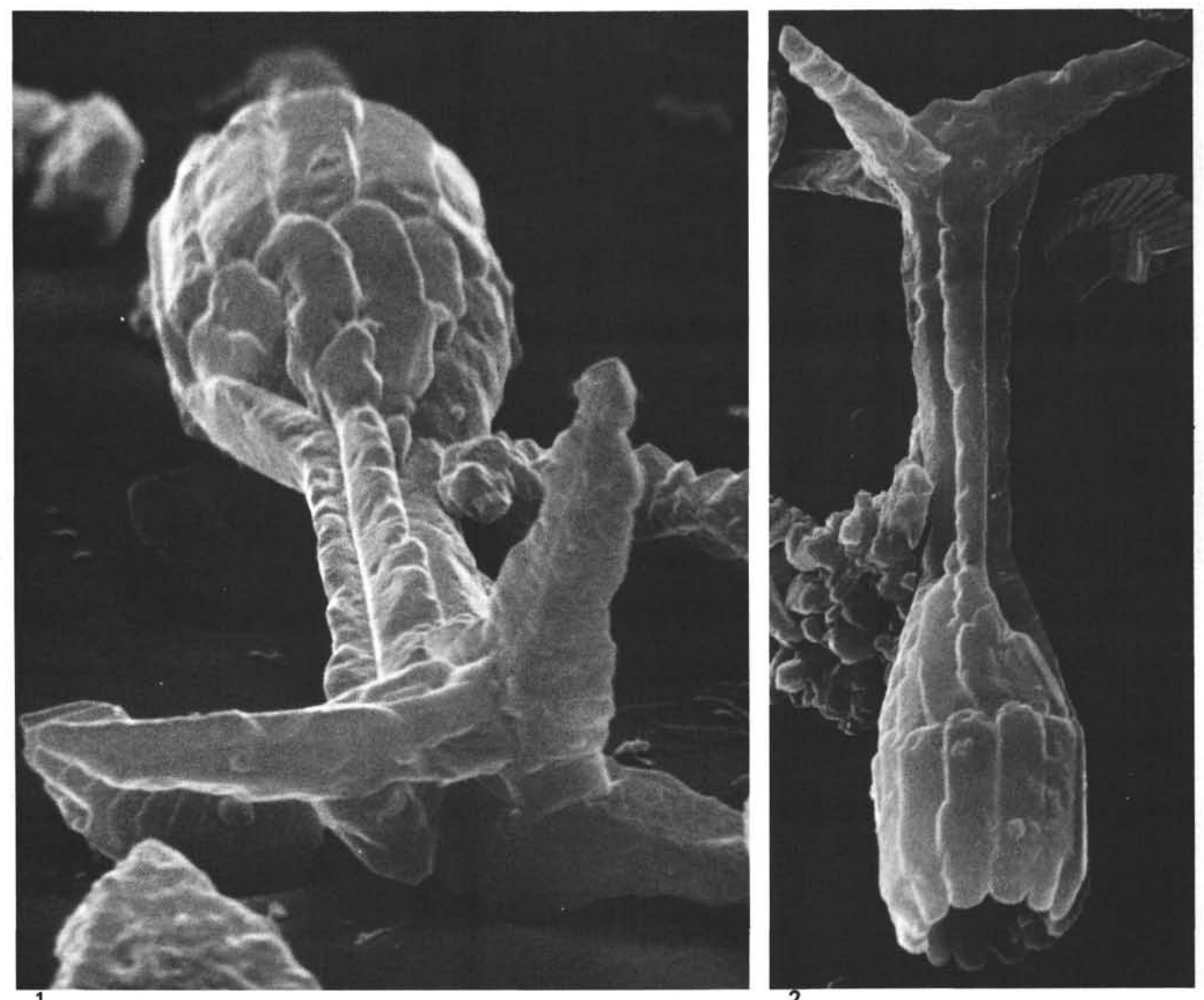

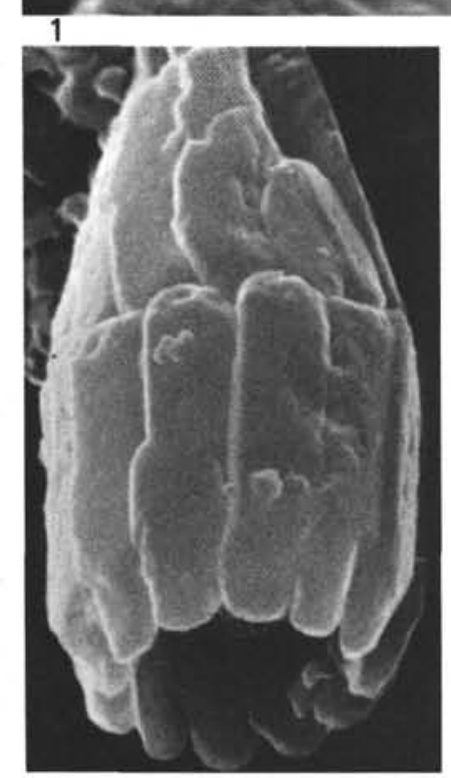

3
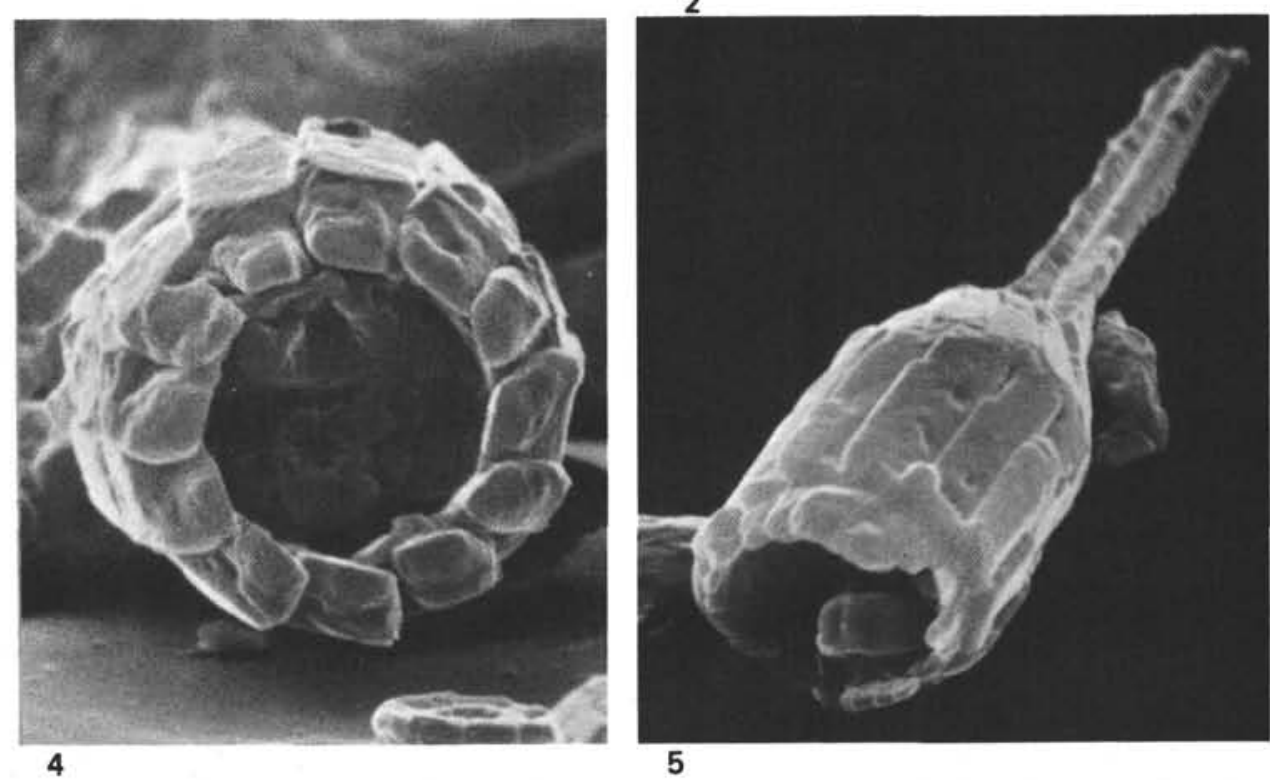
PLATE 2
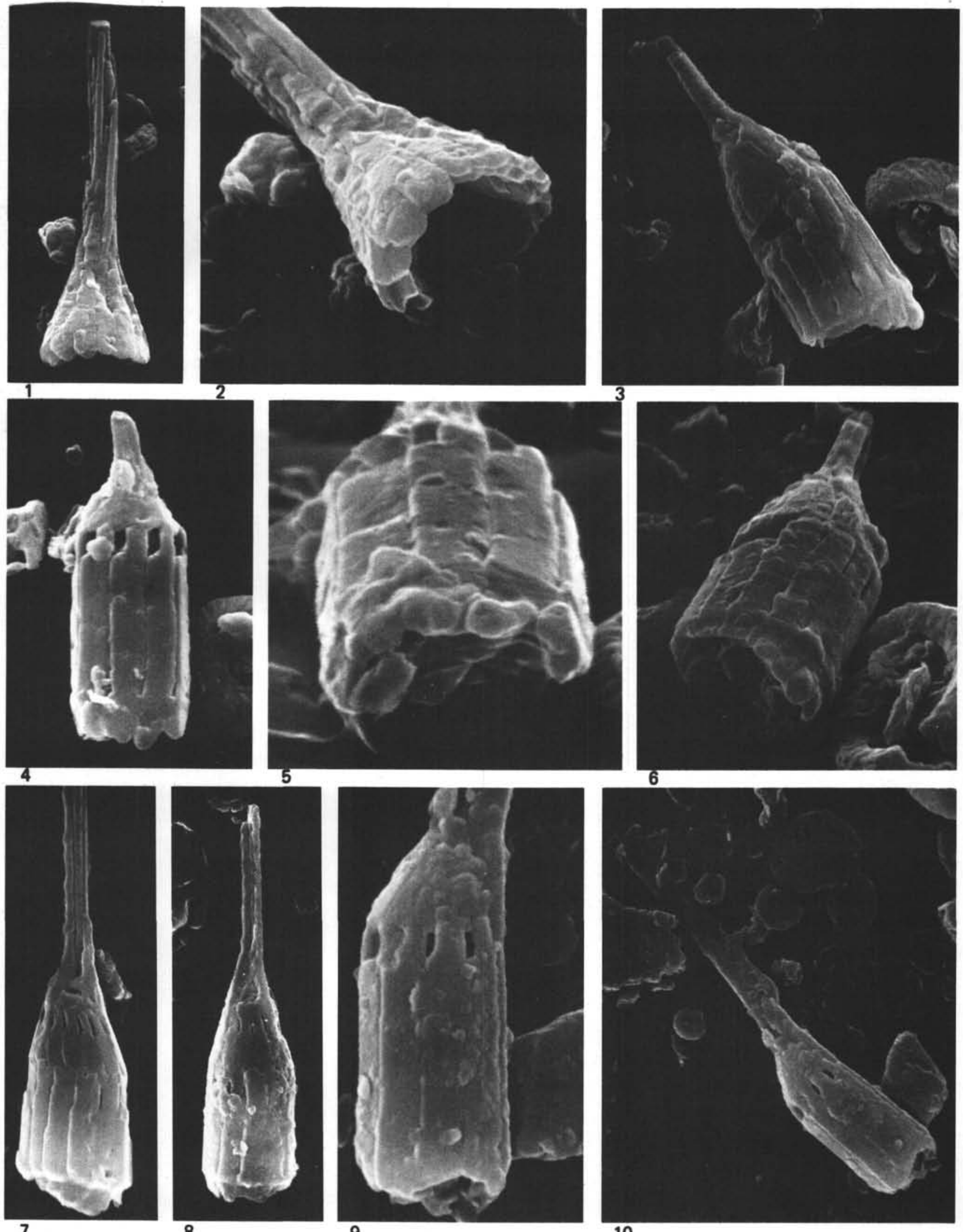

8

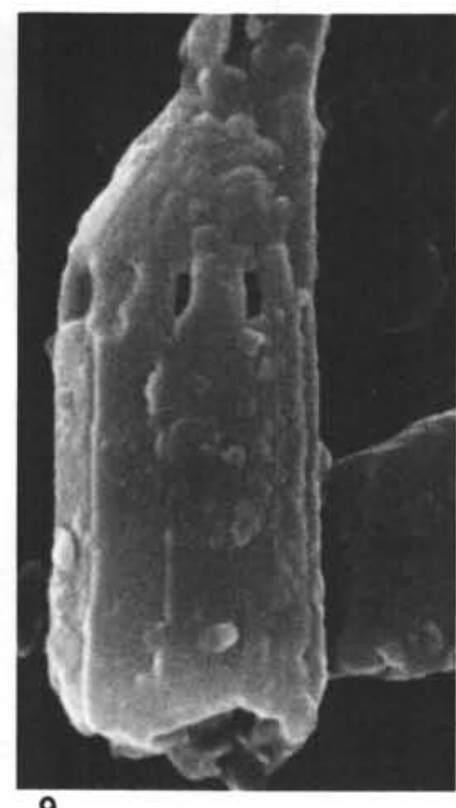

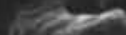
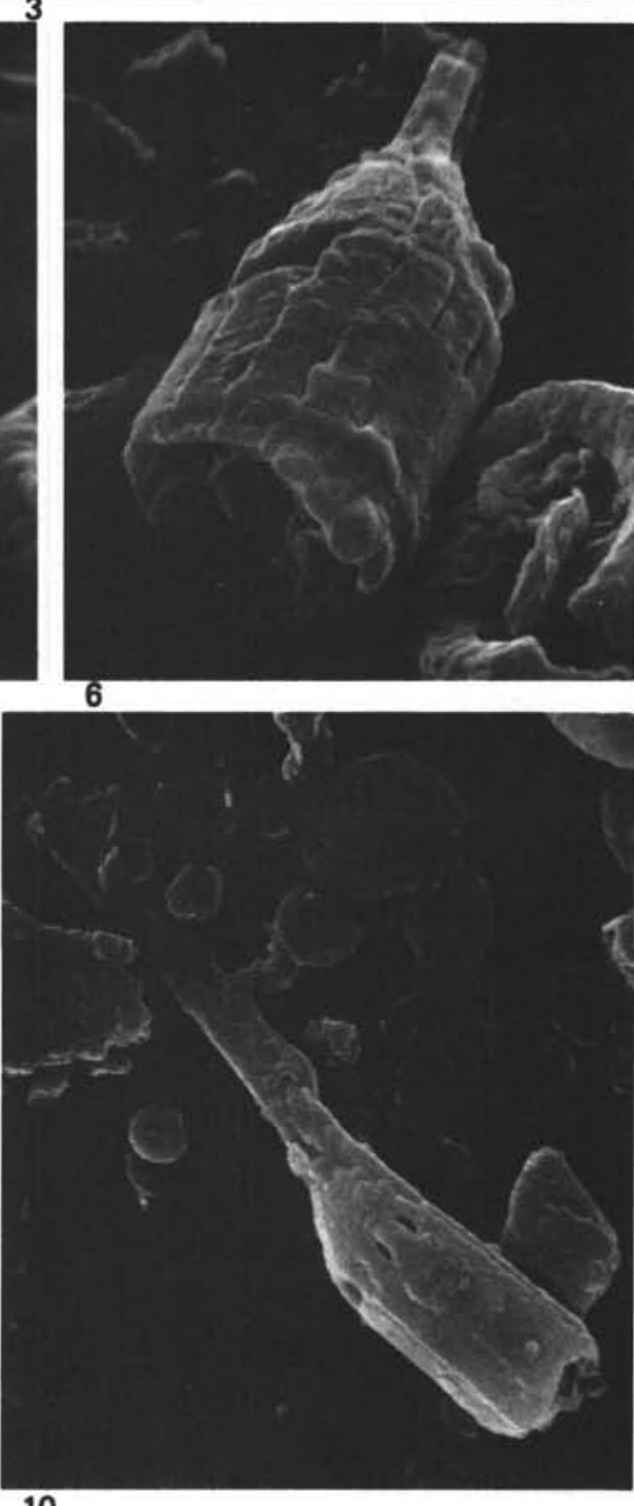
PLATE 3

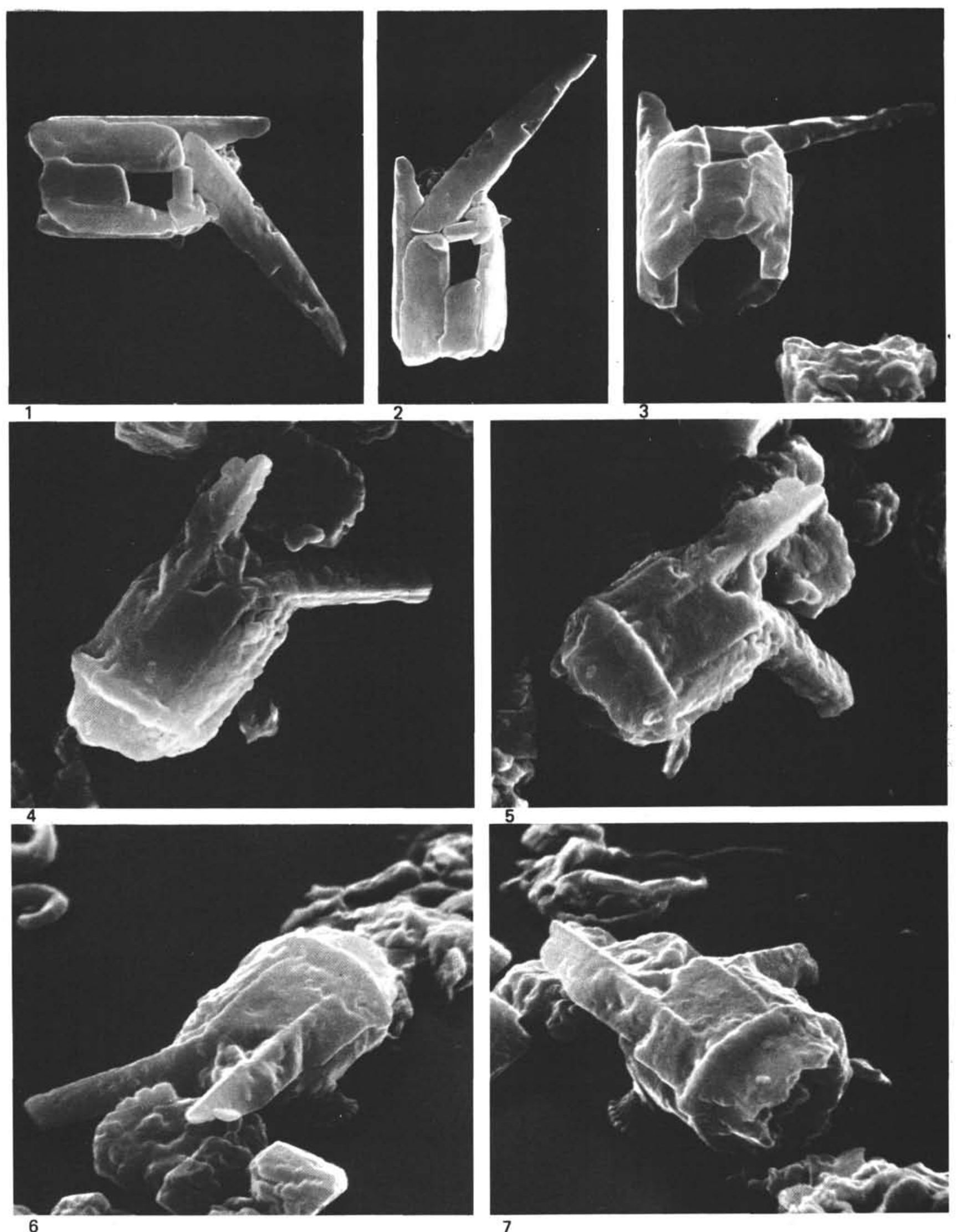




\section{PLATE 4}

Figures 1-3, 8 Lapideacassis trispina Perch-Nielsen, n. sp.

1-3. Holotype. Sample 356-28-3, $70 \mathrm{~cm}$, early Paleocene. $\times 3500$.

Figures 4-6, 7, 9 Lapideacassis multispinata Perch-Nielsen, n. sp. $\times 4900, \times 3500, \times 4900, \times 4900, \times 7000$.

4-6, 9. Holotype. Sample $356-25-5,70 \mathrm{~cm}$, early Paleocene.

(see page 860 )

\section{PLATE 5}

Figures 1, 3, 4, Lapideacassis trispina Perch-Nielsen, n. sp.

$6,7,9 \times 4200, \times 4550, \times 4900, \times 4900, \times 3500, \times 4550$.

$1,4,7$. Sample $356-28-3,70 \mathrm{~cm}$, early Paleocene.

3,6 , 9. Sample $356-25-5,70 \mathrm{~cm}$, early Paleocene.

Figures 2, 5, 8 Scampanella wisei Perch-Nielsen, n. sp.

Holotype. Sample 356-28-3, $70 \mathrm{~cm}$, early Paleocene. $\times 5600, \times 4550, \times 4550$.

(see page 861 )

\section{PLATE 6}

Figures 1-3 Scampanella wisei Perch-Nielsen, n. sp.

Sample $356-23-2,70 \mathrm{~cm}$, late Paleocene. $\times 9000$, $\times 7000, \times 7000$.

Figures 4-6 Scampanella magnifica Perch-Nielsen, n. sp., Maestrichtian, El Kef, Tunisia. $\sim \times 2000$.

Figures 7-9 Scampanella asymmetrica Perch-Nielsen, n. sp. Sample 356-28-3, $70 \mathrm{~cm}$, early Paleocene. $\sim \times 2000$.

Figures 10,11 Scampanella wisei Perch-Nielsen, n. sp., Sample 18-20 354-16-6, $70 \mathrm{~cm}$, late Paleocene, Sample 356-28-3, $70 \mathrm{~cm}$, early Paleocene. $\sim \times 2000$.

Figures 12-14, Scampanella bispinosa Perch-Neislen, n. sp., Sam15-17 ple 356-7-3, $70 \mathrm{~cm}$, middle Eocene, Sample 354-16$6,70 \mathrm{~cm}$, late Paleocene. $\sim \times 2000$.

Figures 21-23, Lapideacassis trispina Perch-Nielsen, n. sp., Sam26,27 ple 356-29-1, $90 \mathrm{~cm}$, early Paleocene, Sample 35628-3, $70 \mathrm{~cm}$, early Paleocene. $\sim \times 2000$.

Figures 24, 25, Lapideacassis multispinata Perch-Nielsen, n. sp., 28-30 Sample 356-28-3, $70 \mathrm{~cm}$, early Paleocene, Sample $356-23-2,70 \mathrm{~cm}$, late Paleocene. $\sim \times 2000$.

Figures 31-33 Lapideacassis cf. L. mariae Black, Sample 356-7-3, $70 \mathrm{~cm}$, middle Eocene. $\sim \times 200$. 
PLATE 4
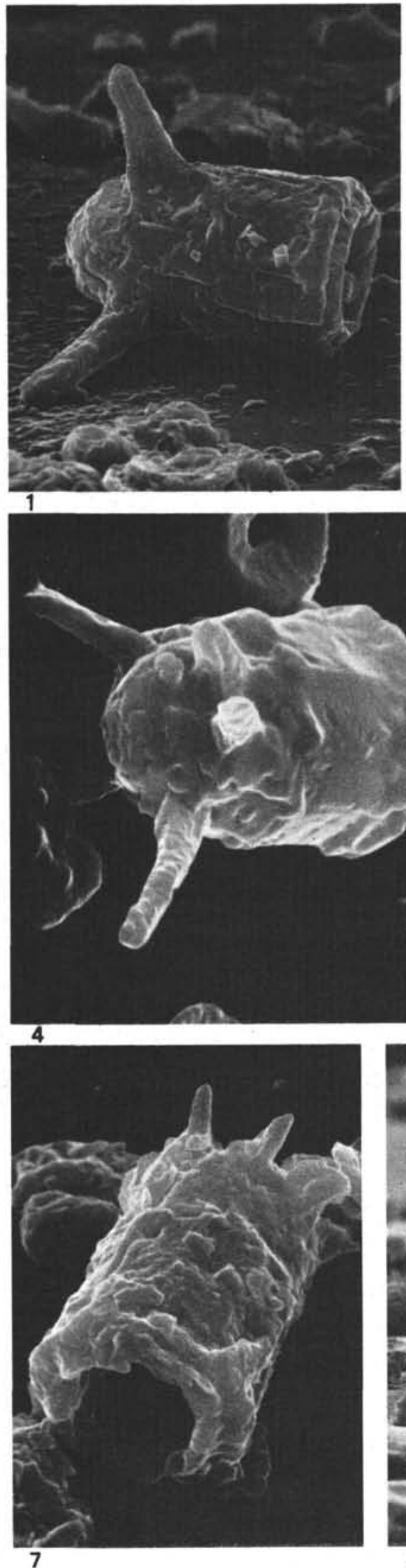
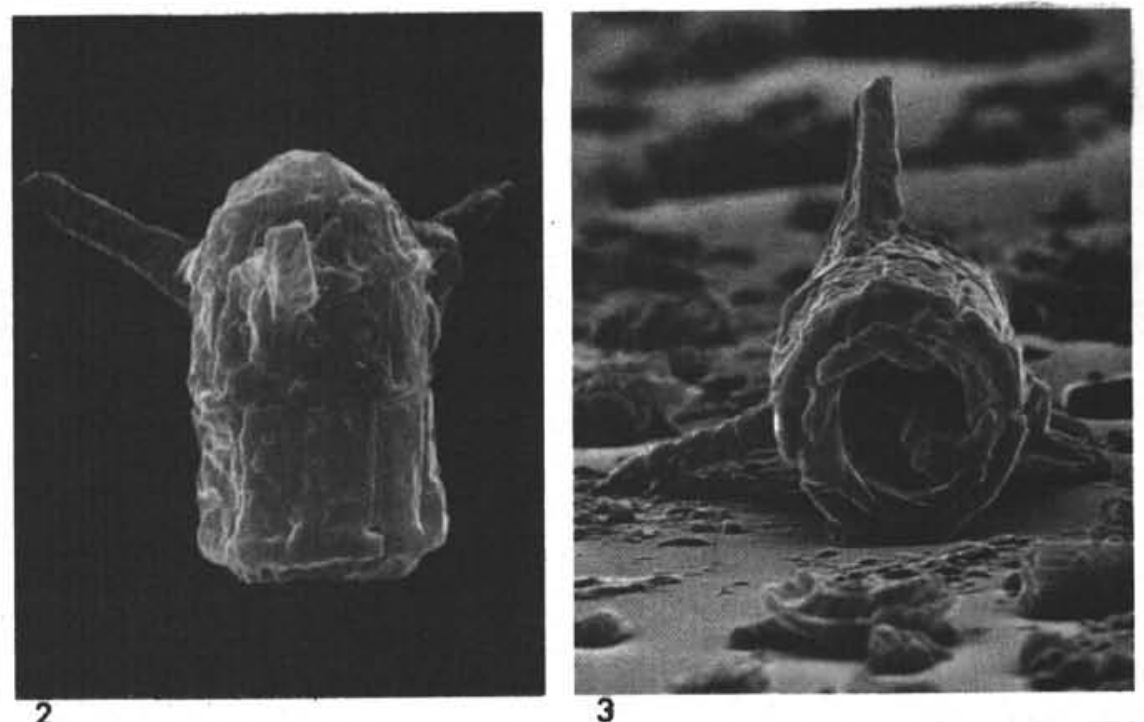

\section{2}

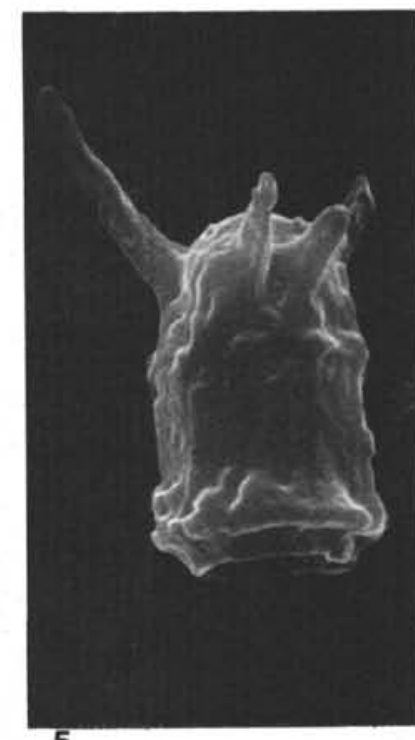

5

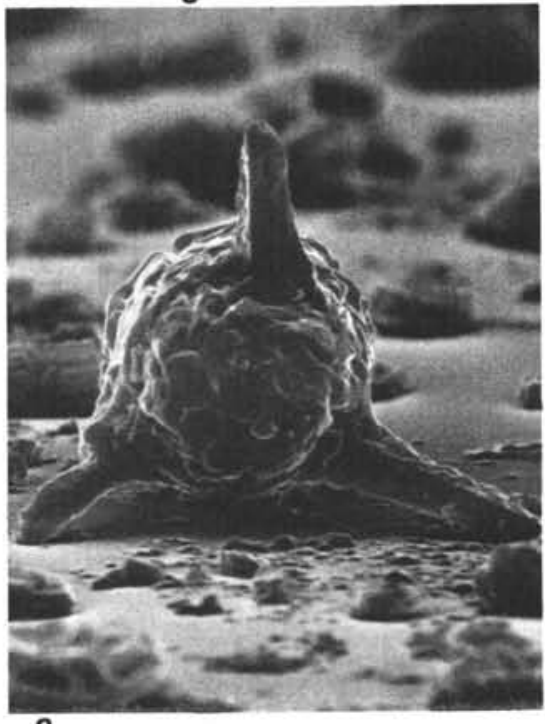

8
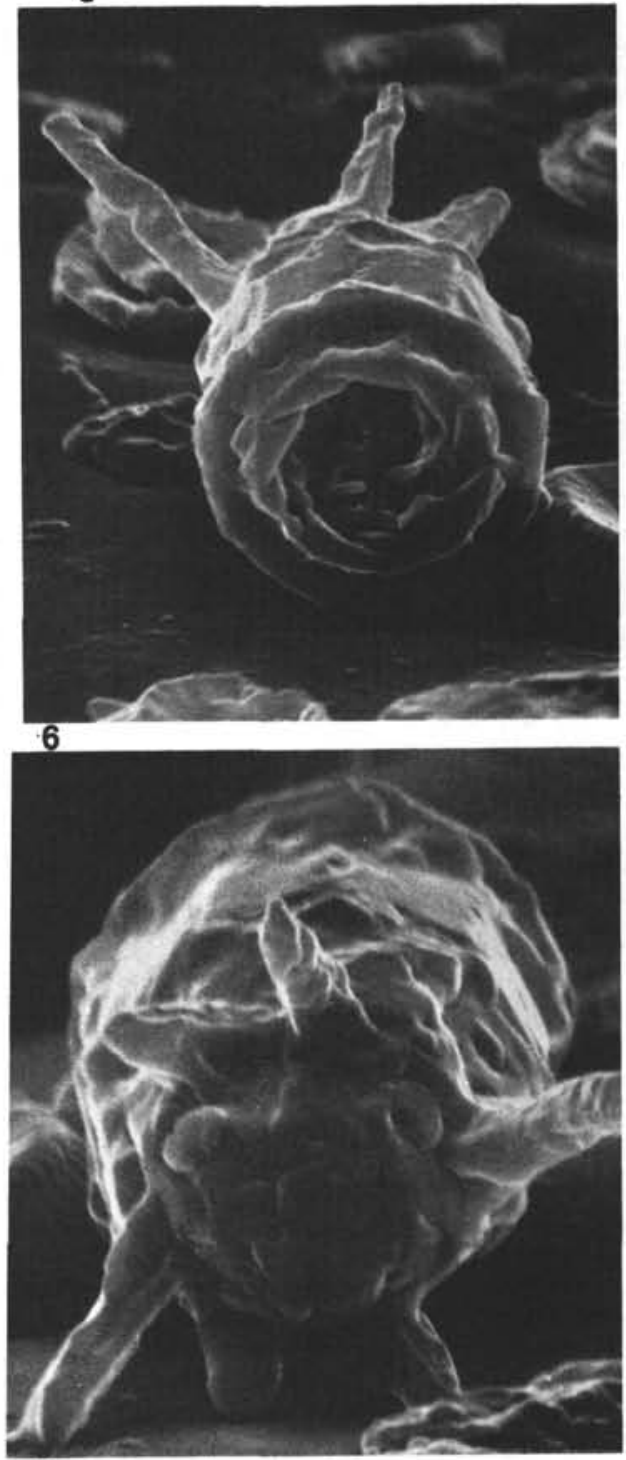

9 
PLATE 5
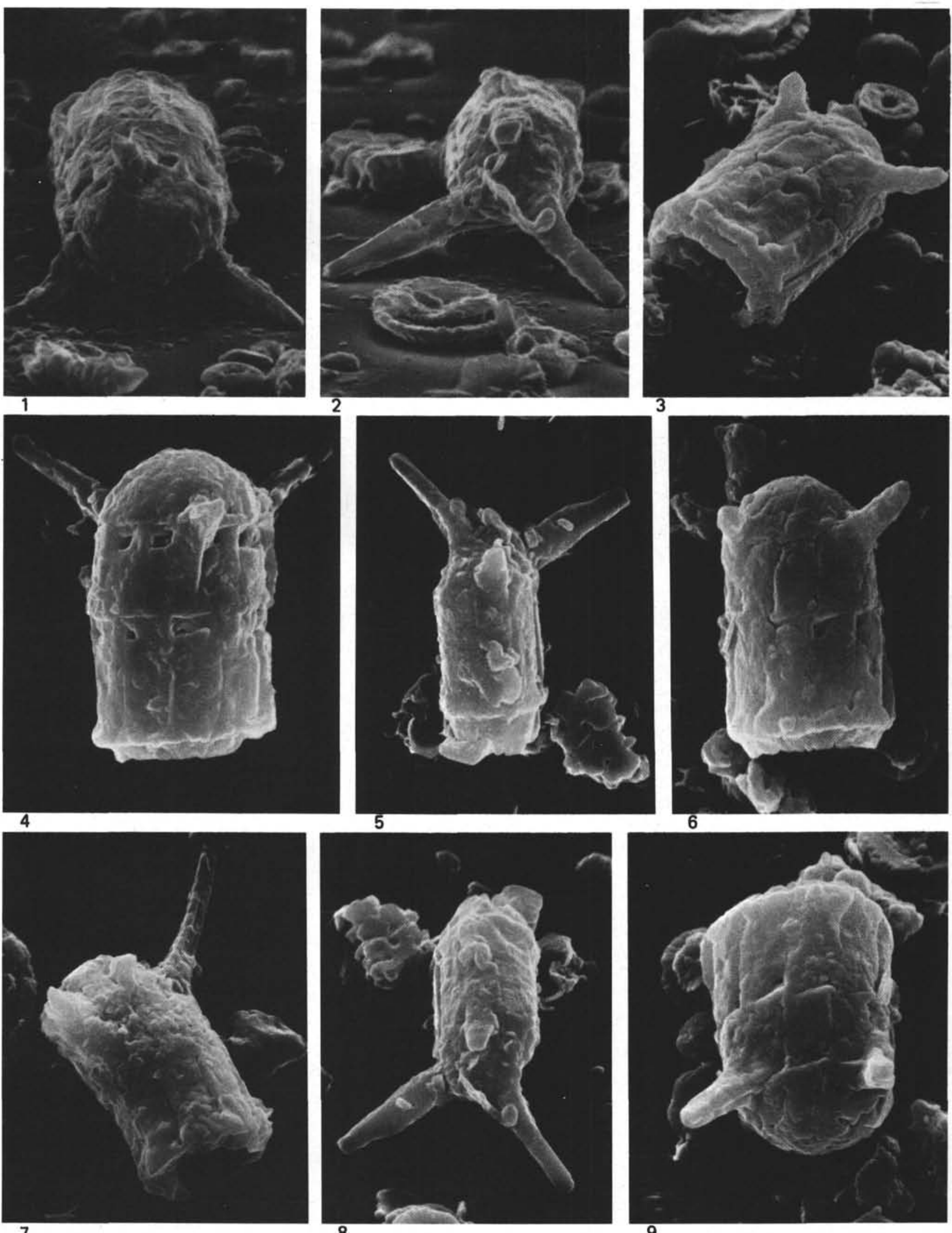

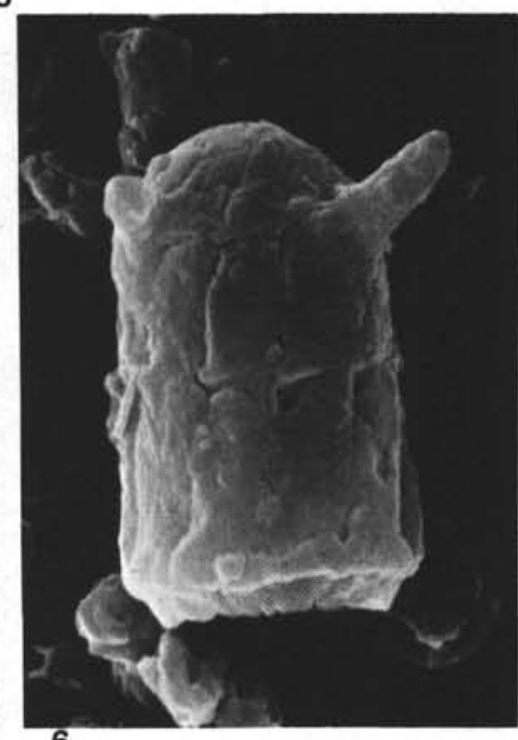

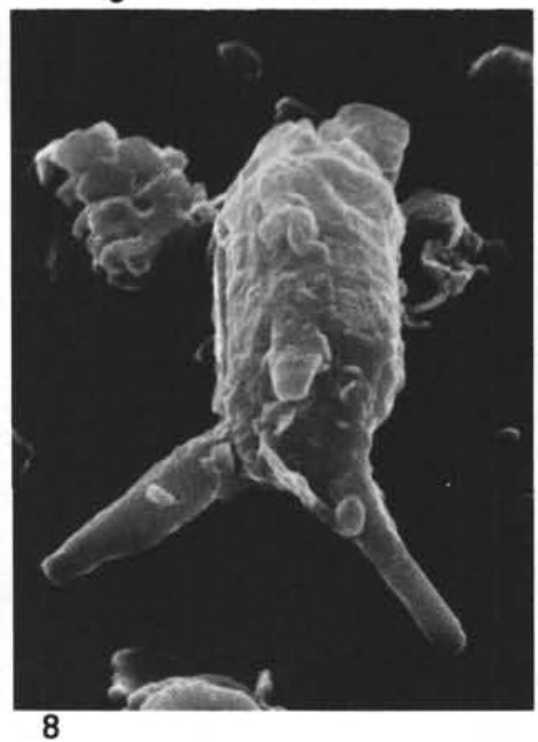

8
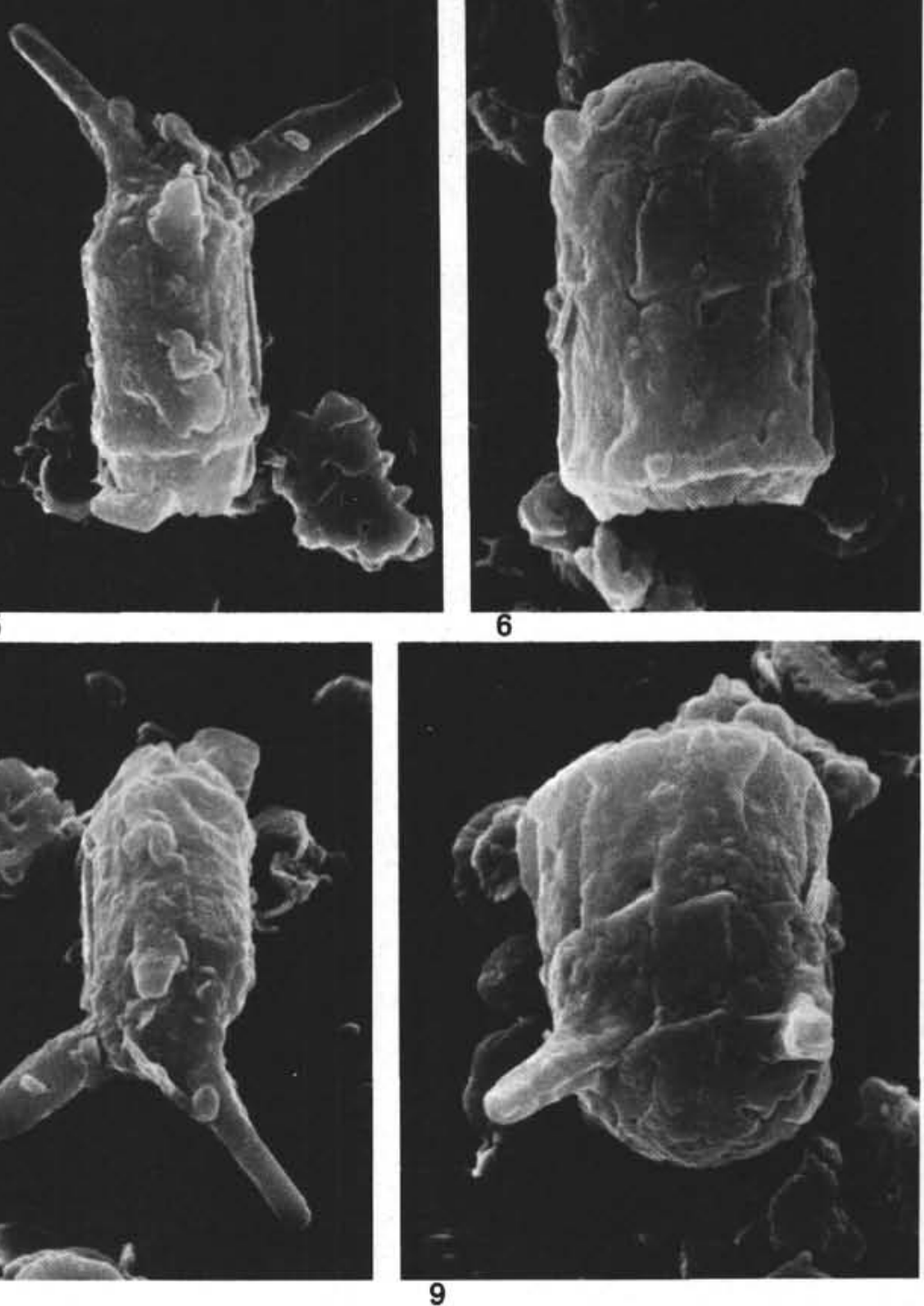
PLATE 6

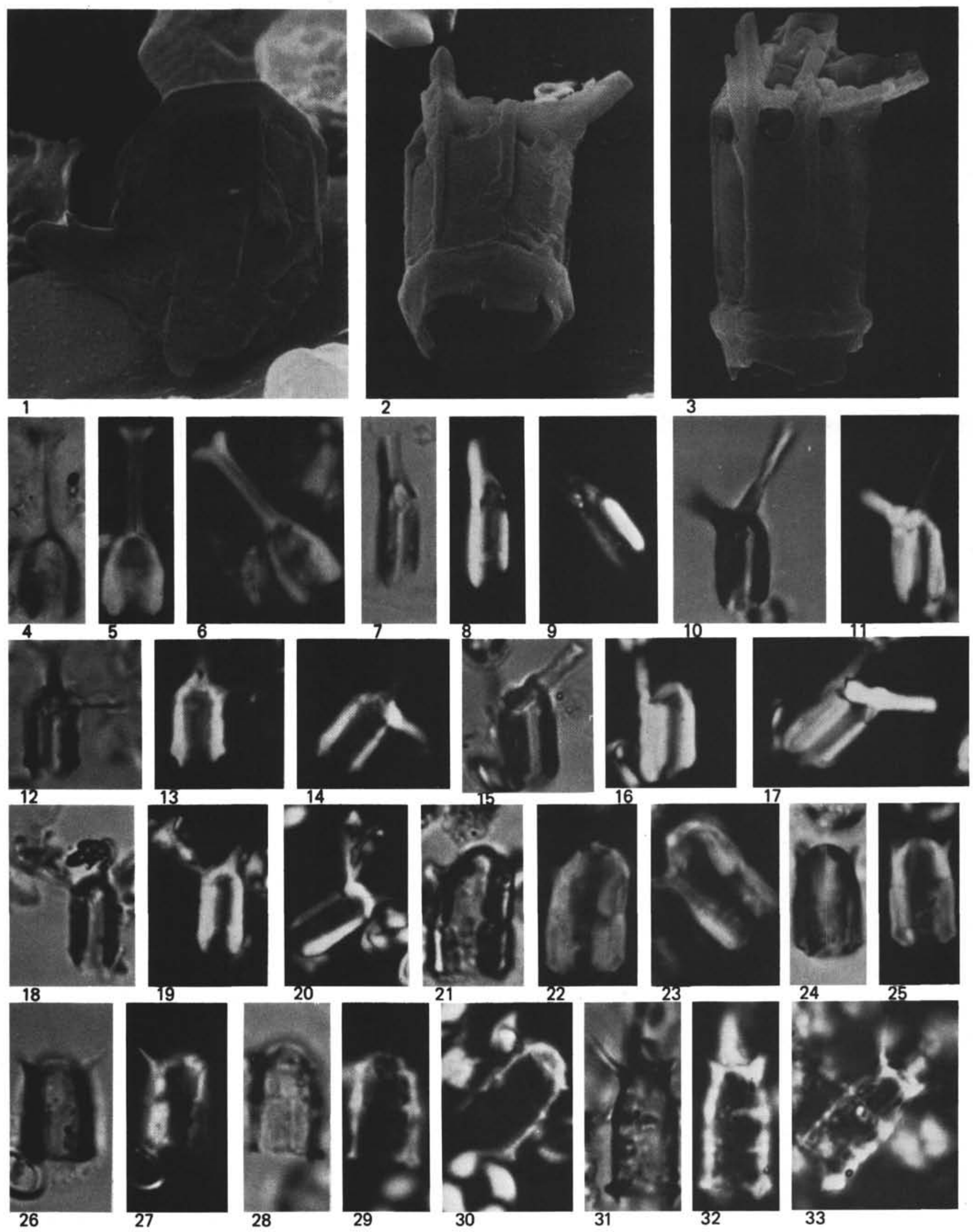

